\title{
SMART SPRAYER DISINSFEKTAN BERBASIS MIKROKONTROLER ATMEGA328
}

\author{
Zulkarnaen ${ }^{1)}$ \\ ${ }^{1)}$ Teknik Informatika. STMIK Syaikh Zainuddin NW \\ Jl. Raya Mataram Lb. Lombok KM.49 Anjani Lombok Timur - NTB \\ e-mail: zolcakep@gmail.com
}

\begin{abstract}
ABSTRAK
Pada masa pandemi covid 19 yang kita alami saat ini, berbagai inovasi teknologi diciptakan sebagai langkah awal dalam memutus mata rantai penyebaran virus corona. Salah satu cara yang bisa diimplementasikan dalam memutus mata rantai pandemi covid 19 khususnya di area publik adalah dengan penyemprotan cairan disinfektan yang bisa dilakukan secara terus menerus. Optimalisasi penyemprotan cairan disinfektan dapat dilakukan dengan memanfaatkan teknologi yang mampu bekerja secara otomatis. Penelitan ini membuat sebuah alat sprayer camber disinfektan sebagai salah satu inovasi teknologi. Otomatisasi sprayer disinfektan dapat dilakukan dengan memanfaatkan mikrokontreler ATemega328 sebagai mesin otomatis untuk mengaktifkan pompa sprayer berdasarkan deteksi objek yang ada disekitarnya dengan bantuan sensor ultrasonic. Penentuan jarak pembacaan objek sangat menentukan kinerja dari sensor ultrasonic dalam memberikan input ke mikrokontroler. Sistem smart sprayer tersebut mampu mengaktifkan pompa DC 12Volt dengan tegangan 5 ampere. Sistem kontrol smart sprayer disinfektan ini bisa diterapkan pada pintu gerbang atau lorong yang berada di pusat keraimaian.
\end{abstract}

Kata Kunci: Mikrokontroler, Atmega328, Arduino, Sprayer, Disinfektan

\begin{abstract}
During the pandemic covid 19 we are experiencing at this time, various technological innovations are created as the first step in breaking the chain of corona virus. One way that can be implemented in breaking the covid pandemic chain of 19, especially in public areas is by spraying a disinfectant liquid that can be done continuously. Optimization of spraying disinfectant liquid can be done by utilizing technology that is able to work automatically. This research makes a disinfectant sprayer chamber as a technological innovation. Automation of disinfectant sprayers can be done by utilizing the ATemega328 microcontroller as an automatic machine to activate the sprayer pump based on the detection of objects that are around it with the help of an ultrasonic sensor. Determination of the distance reading of the object greatly determines the performance of the ultrasonic sensor in providing input to the microcontroller. The smart sprayer system is capable of activating a 12Volt DC pump with a voltage of 5 amperes. This smart sprayer disinfectant control system can be applied to the gate or hallway at the center of the crowd.
\end{abstract}

Keywords: Microcontroller, Atmega328, Arduino, Sprayer, Disinfectant

\section{Pendahuluan}

$\mathrm{P}$ ada masa pandemi covid 19 yang kita alami saat ini, sudah pasti semua orang akan berupaya menciptakan inovasi teknologi sebagai langkah awal dalam memutus mata rantai penyebaran virus corona. Penyebaran virus covid 19 hampir di semua negara yang ada di dunia tidak terkecuali indonesia tjuga tidak luput dari epidemi covid 19 ini. Penerapan pola hidup sehat tentu menjadi salah satu ikhtiar yang dapat kita lakukan untuk memastikan lingkukang sekitar kita benar-benar steril dari bakteri maupun virus.

Pesatnya perkembangan berbagai perangkat teknologi saat ini sebisa mungkin dapat dimaksimalkan. Salah satu cara yang bisa diimplementasikan dalam rangka memutus mata rantai pandemi covid 19 khususnya di area publik adalah dengan penyemprotan cairan disinfektan yang bisa dilakukan secara terus menerus. Ketika penyemprotan itu dilakukan secara masal dan berkala, sudah tentu akan menimbulkan permasalahan baru yakni kebutuhan tenaga atau operator disinfektan. Penyemprotan cairan disinfektan tentu tidak akan maksimal apabila dilakukan secara manual lebih-lebih bagi masyarakat yang berada di tempat-tempat umum atapun sarana publik lainnya seperti perkantoran maupun pusat perbelanjaan bahkan pasar tradisonal, hal ini dikarenakan luasnya area dan banyaknya masyarakat yang akan dilayani. Optimalisasi penyemprotan cairan disinfektan tersebut dapat dilakukan dengan memanfaatkan teknologi yang dapat bekerja secara otomatis. 
Penelitan ini membuat sebuah alat sprayer camber disinfektan sebagai salah satu inovasi teknologi yang dapat diterapkan dalam upaya pencegahan penyebaran pandemi covid 19 ini. Otomatisai spryer disinfektan tersebut dapat dilakukan dengan memanfaatkan mikrokontreler atemega 328 sebagai mesin otomatis untuk mengaktifkan pompa sprayer berdasarkan deteksi objek yang ada disekitarnya dengan bantuan sensor ulrasonic yang dapat diprogram secara optimal. Smart sprayer disinfektan ini dibuat dengan memanfaatkan perkembangan teknologi Internet Of Things (IoT). Perangkat fisik (hardware/embedded system) dalam infrastruktur Internet of Things merupakan hardware yang tertanam (embedded) dengan elektronik, perangkat lunak, sensor dan juga konektivitas. Perangkat embedded system melakukan komputasi untuk pengolahan data dari input sensor dan beroperasi dalam infrastruktur internet.

\section{STUDI PUSTAKA}

Bab ini membahas teori penunjang yang digunakan dalam pembuatan sistem smart sprayer chamber disinfektan yang meliputi: sensor ultrasonic HC-SFR04, Mikrokontroler ATMega 328, Relay serta komponen-komponen pendukung lainnya yang digunakan dalam perancangan.

\section{A. Mikrokontroler}

Mikrokontroler adalah suatu chip berupa IC (Integrated Circuit) yang dapat menerima sinyal input, mengolahnya dan memberikan sinyal output sesuai dengan program yang diisikan ke dalamnya[1]. Sinyal input Mikrocontroller berasal dari sensor yang merupakan informasi dari lingkungan sedangkan sinyal output ditujukan kepada aktuator yang dapat memberikan efek ke lingkungan[4].

Mikrocontroler pada dasarnya adalah komputer dalam satu chip, yang di dalamnya terdapat mikroprosesor, memori, jalur Input/Output (I/O) dan perangkat pelengkap lainnya. Kecepatan pengolahan data pada Mikrocontroller lebih rendah jika dibandingkan dengan PC[4].

Pada PC kecepatan mikroprosesor yang digunakan saat ini telah mencapai orde $\mathrm{GHz}$, sedangkan kecepatan operasi Mikrocontroler pada umumnya berkisar antara $1-16 \mathrm{MHz}$. Begitu juga kapasitas RAM dan ROM pada PC yang bisa mencapai orde Gbyte, dibandingkan dengan Mikrocontroler yang hanya berkisar pada orde byte/Kbyte.

Gambar chip mikrokontroler terdapat pada gambar 1 sebagai berikut.

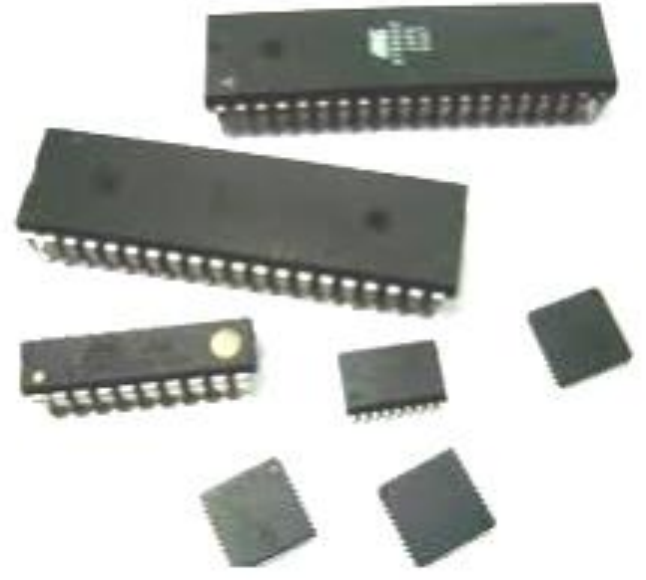

Gambar 1. Chip Mikrokontroler

\section{B. Arduino}

Arduino adalah board berbasis mikrokontroler pada ATMega 328. Board ini memiliki 14 digital input/output pin (dimana 6 pin dapat digunakan sebagai output PWM), 6 input analog, $16 \mathrm{MHz}$ osilator kristal, koneksi USB, jack listrik dan tombol reset[1]. Pin - pin ini berisi semua yang diperlukan untuk mendukung mikrokontroler, hanya terhubung ke komputer dengan kabel USB atau sumber tegangan bisa didapat dari adaptor $\mathrm{AC}-\mathrm{DC}$ atau baterai untuk menggunakannya[4]. Arduino UNO dilengkapi dengan static random access memory (SRAM) berukuran $2 \mathrm{~KB}$ untuk memegang data, flash memory berukuran $32 \mathrm{~KB}$, dan erasable programmable read- only memory (EEPROM) untuk menyimpan program.

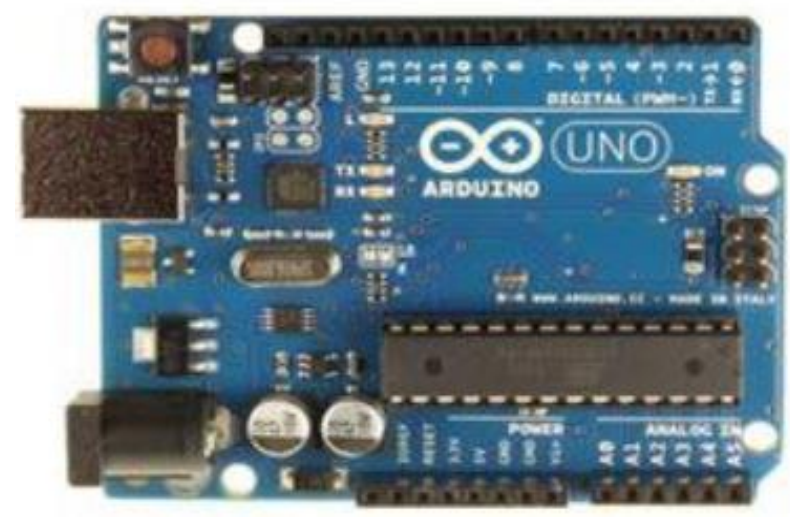

Gambar 2. Board Arduino

Arduino merupakan kit elektronik atau papan rangkaian elektronik open source yang di dalamnya terdapat komponen utama yaiut sebuah chip mkrokontroler dengan jenis AVR dari perusahaan Atmel. Spesifikasi dari arduino uno dapat dilihat pada tabel 1 berikut. 
Tabel 1. Spesifikasi Arduino Uno

\begin{tabular}{|l|l|}
\hline \multicolumn{1}{|c|}{ Mikrokontroller } & \multicolumn{1}{c|}{ ATMega328 } \\
\hline Tegangan Pengoperasian & $5 \mathrm{~V}$ \\
\hline $\begin{array}{l}\text { Tegangan Input yang dis- } \\
\text { arankan }\end{array}$ & $7-12 \mathrm{~V}$ \\
\hline Batas Tegangan Input & $6-20 \mathrm{~V}$ \\
\hline Jumlah Pin I/O Digital & 14 Pin Digital \\
\hline Jumlah Pin Input Analog & 6 Pin \\
\hline Arua DC tiap Pin I/O & $40 \mathrm{~mA}$ \\
\hline Arus DC untuk Pin 3,3 V & $50 \mathrm{~mA}$ \\
\hline Memory Flash & $\begin{array}{l}32 \mathrm{~KB}(\text { ATMega 328) } \\
\text { sekitar 0,5 digunakan oleh } \\
\text { bootloader }\end{array}$ \\
\hline SRAM & 2 KB (ATMega 328) \\
\hline EPROM & $1 \mathrm{~KB}($ ATMega 328) \\
\hline Clock Speed & $16 \mathrm{MHz}$ \\
\hline
\end{tabular}

\section{Relay}

Komponen ini berfungsi sebagai saklar elektronik. Relay akan aktif ketika diberi input high dari mikrokontroler, dan relay ini berfungsi sebagai sistem pengsaklaran untuk solenoid. Relay memiliki 3 pin yang digunakan untuk mengontrol relay yaitu VCC, GND dan IN, dimana VCC dan GND sebagai power untuk modul relay, sedangkan IN sebagai input untuk mengontrol Relay [2].

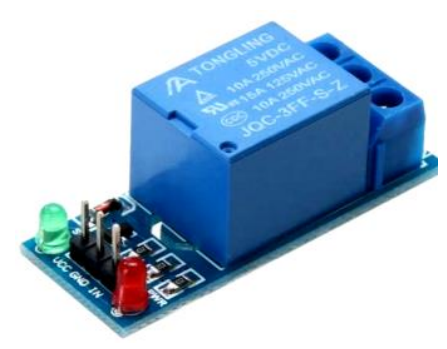

Gambar 3. Relay 1 chanel

spesifikasi dari modul relay 1 chanel ini sebagai berikut.

- Hubungi 10A dan 250V AC atau 30V DC saat ini.

- Setiap saluran memiliki indikasi LED.

- Tegangan koil $12 \mathrm{~V}$ per saluran.

- Tegangan pengoperasian kit 5-12 V

- Input sinyal 3-5 V untuk setiap saluran.

- Tiga pin untuk mengontrol relay

\section{Sensor Ultrasonic}

Sensor ultrasonik adalah sensor yang bekerja berdasarkan prinsip pantulan gelombang suara dan digunakan untuk mendeteksi keberadaan suatu objek tertentu di depannya, frekuensi kerjanya pada daerah diatas gelombang suara dari $40 \mathrm{KHz}$ hingga $400 \mathrm{KHz}$. Sensor ultrasonik terdiri dari dari dua unit, yaitu unit pemancar dan unit penerima [2].

Sensor PING mendeteksi jarak objek dengan cara memancarkan gelombang ultrasonik ( $40 \mathrm{KHz}$ ) selama $\mathrm{t}=200$ us kemudian mendeteksi pantulannya. Sensor PING memancarkan gelombang ultrasonik sesuai dengan kontrol dari Mikrokontroler pengendali ( pulsa trigger dengan tout min 2 us ). Kisaran jarak yang dapat di baca sensor ultrasonic ping ini adalah $3 \mathrm{~cm}$ sampai $3 \mathrm{~m}$ dan sudut pancaran dari sensor jarak ultrasonic ping adalah dari $0^{\circ}$ sampai dengan $30^{\circ}[2]$.

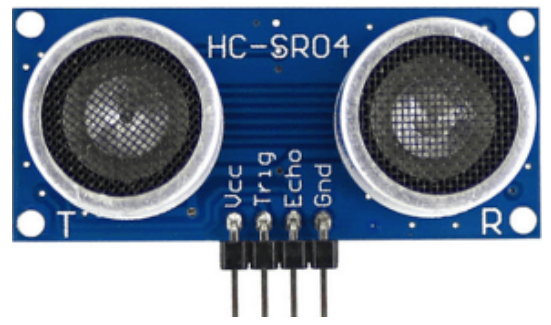

Gambar 4. Sensor Ultrasonic HC-SR04

1. Spesifikasi sensor Ultrasonic HC-SR04:

- Jarak deteksi antara $2 \mathrm{~cm}-300 \mathrm{~cm}$

- Tingkat kepresisisan pengukuran jarak $\pm 3 \mathrm{~mm}$

- Tegangan operasional $5 \mathrm{Vdc}$

- Sudut sensor < 15 derajat

- Konsumsi arus berkisar $2 \mathrm{~mA}$

- Dimensi modul $45 \mathrm{~mm}$ x 20mm

2. Bagian-bagian dari sensor ultrasonic antara lain:

- Piozoelektrik

Berfungsi sebagai alat pengubah energi listrik dijadikan menjadi energi mekanik. Material dasar yang terdapat pada piezoelektrik yang menghasilkan medan listrik saat terjadi tekanan mekanis dan sebaliknya. Misalnya saja rangkaian pengukur dioperasikan pada mode pulsa dengan unsur piezoelektrik yang sama, sehingga bisa digunakan sebagai mode reiceiver dan transmitter. Frekuensi dihasilkan tergantung dari osilator yang terpasang dan itu akan disesuaikan dengan frekuensi kerja dari transduser.

- Transimiter

Merupakan alat yang mempunyai peran sebagai pemancar gelombang dengan frekuensi $40 \mathrm{kHz}$ yang bersumber dari isolator. Frekuensi tersebut dihasilkan dari rangkaian osilator serta amplifier sinyal/penguat sinyal. Pada amplifier sinyal akan menghasilkan sinyal listrik yang diumpankan ke piezoelektrik dan terjadilah reaksi mekanik. Pada proses itu dimana piezoelektrik akan memancarkan gelombang sesuai dengan sumber osilatornya.

- Receiver

Terdiri dari transduser ultrasonik yang memakai piezoelektrik juga yang difungsikan sebagai penerima gelombang pantulan. Bahan piezoelektrik mempunyai reaksi yang reversible, terdapat elemen keramik yang berfungsi sebagai pembangkit tegangan listrik. Pada waktu gelombang datang dengan kriteria frekuensi yang 
resonan dan pada saat itu akan menggetarkan bahan piezoelektrik

\section{E. Pompa Air}

Pompa adalah mesin atau peralatan meknis yang digunakan untuk menaikan cairan dari dataran rendah ke dataran tinggi atau untuk mengalirkan cairan dari daerah bertekanan rendah ke daerah yang bertekanan tinggi dan juga sebagai penguat laju aliran pada suatu sistem jaringan perpipaan [3]. Hal ini dicapai dengan membuat suatu tekanan yang rendah pada sisi masuk atau suction dan tekanan yang tinggi pada sisi keluar atau discharge dari pompa.

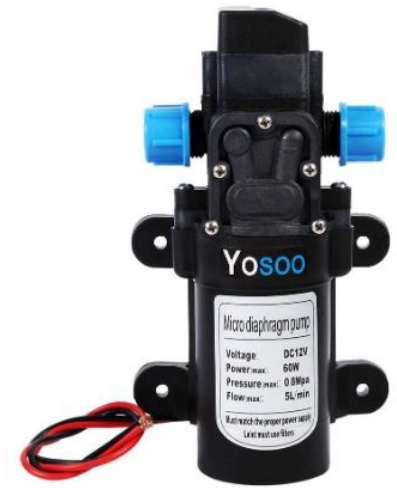

Gambar 5. Pompa Air DC

Spesifikasi pompa air yang digunakan sebagai berikut:

Spesifikasi:

Volt

: DC12V

Daya

: 60W

Tingkat Aliran

$: 5 \mathrm{~L} / \mathrm{mnt}$

Tekanan Kerja Maks

Pumping Head

: 116psi (0.8MPA)

Kisaran

: 50 meter

Ukuran

Panjang Garis

7 meter

: 9,9 x 16,7cm / 3,9 "x 6,6"

: $29 \mathrm{~cm} / 11,4$ "

\section{METODE PENELITIAN}

Metode yang digunakan pada penelitian ini yaitu metode experimental, yang merupakan kombinasi antara perancangan dan pembuatan sistem.

\section{A. Perancangan Sistem}

Perancangan sistem otoamatis smart sprayer bilik disinfektan ini menggunakan mikrokontroler Atmega328 dibagi menjadi dua bagian yaitu perancangan hardware dan perancangan software.

Perancangan hardware terbagi menjadi dua bagian yaitu pembuatan bilik disinfektan dan perakitan sistem kontrol sprayer otomatis menggunakan kit arduino uno yang terdiri dari midul relay satu chanel, buzer serta modul sensor ultrasonic. Perancangan software merupakan pembuatan program mikrokontroler menggunakan IDE Arduino.

Berikut ini merupakan tahapan yang dilakukan dalam perancangan hardware maupun software antara lain:

1. Perancangan Bilik Disinfektan

Pembuatan bilik disinfektan pada penelitian ini menggunakan baja ringan jenis holo dengan diameter pipa kotak $4 \times 4$.

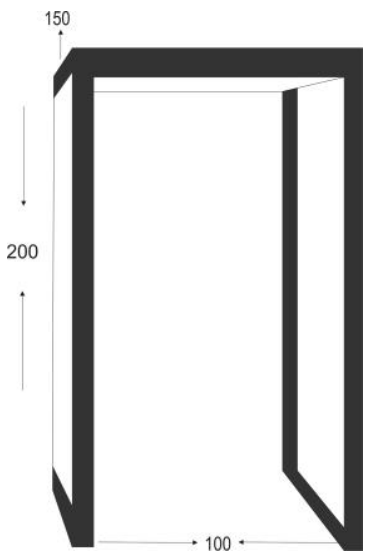

Gambar 5. Rancangan Rangka sprayer disinfektan
Spesifikasi:
Dimensi
: Tinggi $200 \times 100 \times 150$
Rangka Tiang
: Holo $614 \times 4$ tebal 1.8
Rangka Palang
: Holo $614 \times 4$ tebal 1.8
Dinding
: Acrilick $3 \mathrm{~mm}$

2. Rangacangan Sistem Kontrol

Berikut ini merupakan rancangan sistem otomatis sprayer disinfektan menggunakan kit arduino uno R3

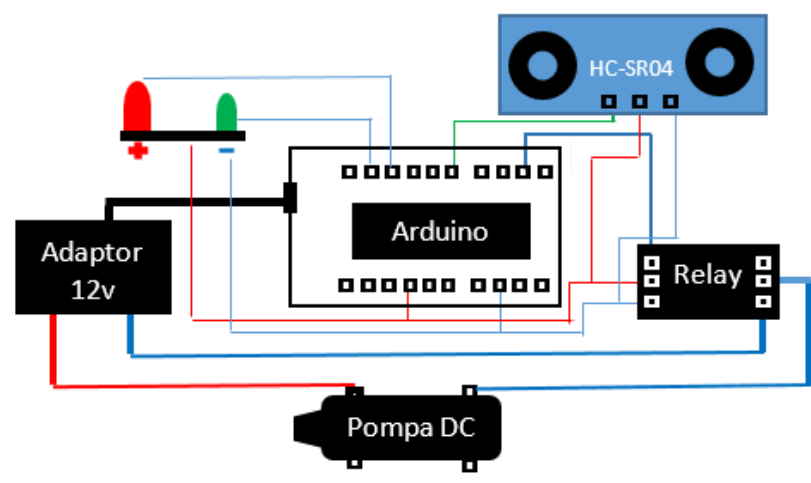

Gambar 6. Rancangan Kontrol Otomatis

Dari gambar 6 di atas dapat dijelaskan bahwa Arduino sebagai pusat instruksi. Arduino berfungsi untuk mendeteksi aktivitas dari mesin yang ditandai dengan LED merah sebagai posisi standbay. Ketika sensor mendeteksi gerakan atau ada objek maka sensor akan mengirimkan sinyal berupa input ke mikrokontroler untuk memberikan input ke relay dengan indikator LED hijau menyala dan membangkitan tegangan dari relaya untuk On Pompa. Lama pompa aktif disuaikan berdasarkan kebutuhan setelah itu LED hijau Of dan LED merah On mendankan proses program sudah dilaksanakan.

3. Perancangan Modul Program

Berikut ini merupakan modul program yang dibuat untuk memberikan instruksi program terhadap komponen-komponen elekrtrik yang 
terhubung langsung dengan arduino uno berdasarkan skema yang terdapat pada gambar 6 .

\#define Buzzer $9 / /$ mendefinisikan pin 4 Arduino sebagai pin Output Buzzer

\#define valve $10 / /$ valve

\#define merah 7 //LAMPU MERAH

\#define hijau 8 //LAMPU HIJAU

\#define trigPin $5 / /$ mendefinisikan pin 5 arduino sebagai trigger pin sensor ultrasonic

\#define echoPin $6 / /$ mendefinisikan pin 6 arduino sebagai echoPin sensor ultrasonic

long duration; // variabel durasi sensor ultrasonic int distance; // jarah dalam centimeter

void setup ()

$$
\{
$$

pinMode(trigPin, OUTPUT); // setting triggerpin sebagai output

pinMode(echoPin, INPUT); // setting echopin sebagai Input

pinMode(10, OUTPUT); // setting valve sebagai Output

pinMode(7, OUTPUT); // setting merah sebagai Output

pinMode(8, OUTPUT); // setting hijau sebagai Output

pinMode(9, OUTPUT); // setting Buzzer sebagai Output

Serial.begin(9600); // setting kecepatan pengiriman serial monitor

\}

void $\operatorname{loop}()\{$

digitalWrite(trigPin,LOW);

delayMicroseconds (3);

digitalWrite(trigPin,HIGH);

delayMicroseconds (5);

digitalWrite(trigPin,LOW);

duration $=$ pulseIn $($ echoPin,HIGH);

digitalWrite(trigPin, $\mathrm{HIGH}$ );

distance $=$ duration $* 0.034 / 2$;

Serial.print("Distance: "); //menampilkan jarak pada serial monitor

Serial.println(distance);

if (distance $<=30$ )

\{

digitalWrite(9,HIGH);

delay(500);

digitalWrite(8,HIGH);

digitalWrite(9,LOW);

delay(500);

digitalWrite(8,HIGH);

digitalWrite(7,LOW);

digitalWrite(10,HIGH); //membaca PIN 2 pada relay,dan memasukan nilai LOW pada saat tidak ada benda yang menghalangi sensor

delay(5000); //waktu pada saat relay mati

digitalWrite(9,HIGH);

delay(500);

digitalWrite(9,LOW);

delay(500);

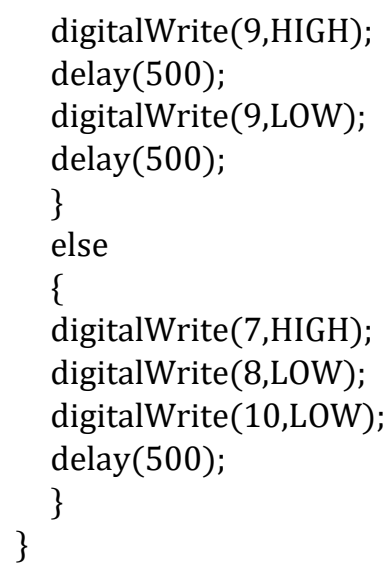

\section{HASIL DAN PEMBAHASAN}

A. Prinsip Kerja Sistem Smart Sprayer Dinsinfektan

1. Sprayer disinfektan otomatis ini bekerja dengan menyemprotkan cairan berupa disinfektan dengan durasi waktu yang dapat di sesuaikan antara 3 hingga 10 detik melalui lubang mata stik sprayer secara otomatis.

2. Sensor ulrasonic akan mendeteksi objek atau gerakan manusia yang ada di dalam bilik dengan radius yang sudah ditentukan sebelumnya. Sinyal sensor ultrasonic tersebut akan dikirim ke arduino sebagai input analog untuk diteruskan ke modul relay.

3. Arduino memeriksa modul program apakah terdapat sinyal gerakan atau terdapat ada objek atau tidak ditandai dengan LED hija Menyala disertai bunyi beep dari alrm/buzer.

4. Modul relay menerima sinyal analog dari arduino kemudian mengaktifkan pompa air untuk menyemprotkan cairan disinfektan

5. Arduino akan memeriksa modul program apakah durasi sensor On berada pada limit maksimal untuk memberikan perintah berupa pemutusan tegangan dari relay ke pompa.

6. LED Merah akan menyala sebagai tanda bahwa sistem sedang berada pada posisi standbay hingga ada objek baru yang dideteksi.

B. Bentuk Fisik Smart Sprayer

Pada gambar 7 dan 8 merupakan bentuk rangkaian fisik yang merupakan hasil akhir dari pembuatan sistem kontrol otomatis smart sprayer. Sebagai berikut:
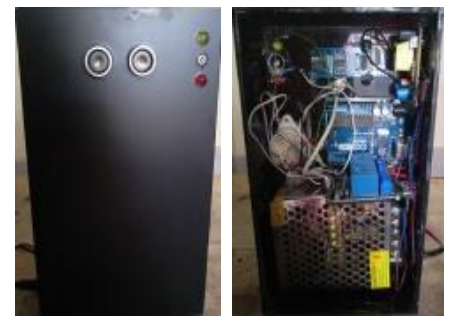

Gambar 7. Alat Kontrol Otomatis Smart Sprayer 
Gambar 8 merupakan dokumentasi penerapan sistem kontrol secara langsung sekaligus uji coba ketahanan alat yang dibuat.

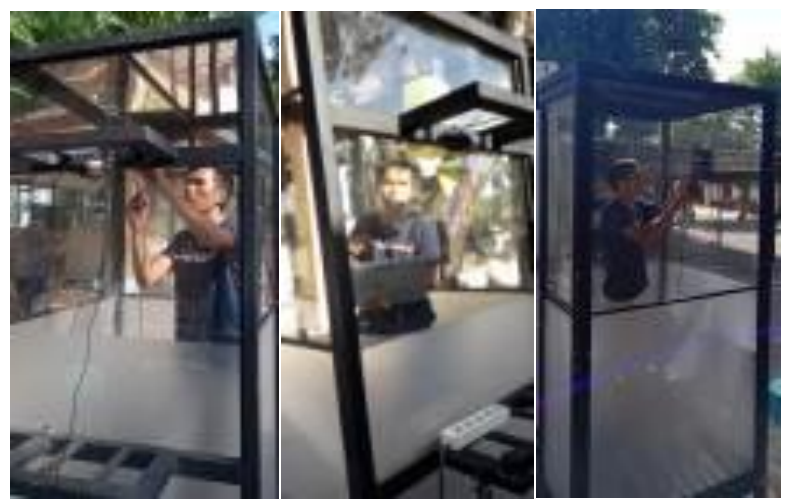

Gambar 8. Proses Pemasangan Kontrol Otomatis

\section{Implementasi Sprayer Disinfekatan Otomatis}

Setelah proses perancangan selsai dilakukan, tahap selanjutnya adalah implementasi kontrol otomatis sprayer disinfektan pada bilik yang sudah di buat sebelumnya. Berikut ini merupakan dokumentasi uji coba smart spryer pada salah satu kabupeten di NTB dalam rangka memutus penyebaran epidemi covid 19.

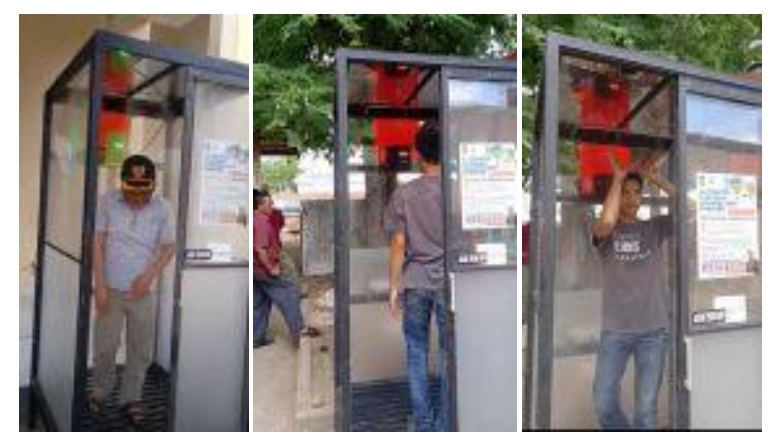

Gambar 9. Uji Coba Sistem Smart Sparayer

Dari gambar 9 di atas, uji coba yang dilakukan di dua tempat yang berbeda. Berdasarkan uji coba yang dilakukan, alat otomatis untuk sprayer disinfektan mampu bekerja dengan baik sesuai dengan instruksi program yang di rancang pada saat pembuatan modul program. Rata-rata durasi pembacaan sensor yang digunakan yaitu antara 3 sampai 5 detik setelah itu lampu indikator merah akan menyala menandakan proses pembacaan sensor sudah selesai.

\section{KesIMPULAN}

Dari hasil uji coba yang dilakukan terhadap sistem otomatis sprayer disinfektan berdasarkan parameter uji yang digunakan dapat disimpulkan sebagai berikut:

1. Penentuan jarak/radius pembacaan objek sangat menentukan kinerja dari sensor ultrasonic dalam memberikan input ke mikrokontroler.

2. Sistem smart sprayer tersebut mampu mengaktifkan pompa DC 12volt dengan tegangan 5 ampere.
3. Sistem kontrol smart sprayer disinfektan ini bisa diterapkan pada pintu gerbang atau lorong jalan yang biasa dilalui oleh banyak orang

\section{UCAPAN TERIMA KASIH}

Ahirnya penulis juga tak lupa mengucapkan terimakasih kepada pihak-pihak yang telah banyak membantu penulis dalam menyelesaikan penelitian ini yang tentu tak dapat penulis sebutkan satu per satu.

\section{DAFTAR PUSTAKA}

[1] Halifa Hendri, "Pembersih Tangan Otomatis Dilengkapi Air Sabun Hardrayer dan LCD Menggunakan Sensor Infrared Berbasis Arduino," Jurnal Teknologi, vol. 8, no. 1, hal. 1-14, april, 2018.

[2] Pranata Wayan A, "Lampu Otomatis dengan Arduino Menggunakan Sensor Ultrasonic dan Relay", Ilmuti.org, 2018-2019

[3] Ratnawati, dkk. "Sistem Kendali Penyiram Tanaman Menggunakan Propeller Berbasis Internet Of Tihings" Jurnal Inspiration, vol 7 no 2, hal 143-154, Desember, 2017.

[4] Mohammad Hariono, "Prototype Rumah Otomatis Menggunakan Mikrokontroler ATmega 328P dengan Konsep IoT Sebagai Kendali Jarak Jauh", Seminar Nasional Fortei7-1, juli, 2018. 